\title{
A Framework for Developing Local E-government
}

\author{
Wichian Chutimaskul and Vithida Chongsuphajaisiddhi \\ School of Information Technology, King Mongkut's University of Technology Thonburi, \\ Pracha-U-Thit Rd, Thungkru, Bangkok 10140, Thailand \\ \{wichian, vithida\}@it. kmutt.ac.th
}

\begin{abstract}
The paper proposes a framework for developing local egovernment. The framework is based on software engineering discipline and its real practice. The framework suggests four perspectives that need to be considered: stakeholders, business drivers, technology drivers, and methodology. It provides a guideline of what to consider in order to set up local egovernment in an appropriate direction. It is then applied in Thai local egovernment context which has a particular characteristic of cluster structure. Finally, the paper also mentions some benefits of knowledge management for Thai local e-government.
\end{abstract}

\section{Introduction}

There are some frameworks which have been proposed for local e-governments in other countries such as England [1], [2], India [3], and Canada [4]. In general, these frameworks suggest various aspects in developing local e-government with emphasis on what to consider in order to deliver government services to citizens. However, there are some other factors that also influence local e-government projects which are not emphasised in these frameworks such as stakeholders, government policies. Hence, this paper suggests a framework for developing local e-government based on software engineering discipline, in an attempt to include broader perspectives.

\section{A Framework for Developing Thai Local E-government}

\subsection{A Framework for Developing Local E-government}

The framework proposed in this paper is based on perspectives which are generally mentioned in the discipline of software engineering, or software development, with its real practice [5], [6], [7], [8]. The framework focuses on an information system with its four perspectives: the stakeholders (players) in the information system, the business drivers influencing the information system, the technology drivers used by the information system, and the methodology used to develop the information system. 
Local e-government can be considered as a kind of information system which is a tool for governance. Thus the framework for local e-government can be developed as shown in Fig. 1.

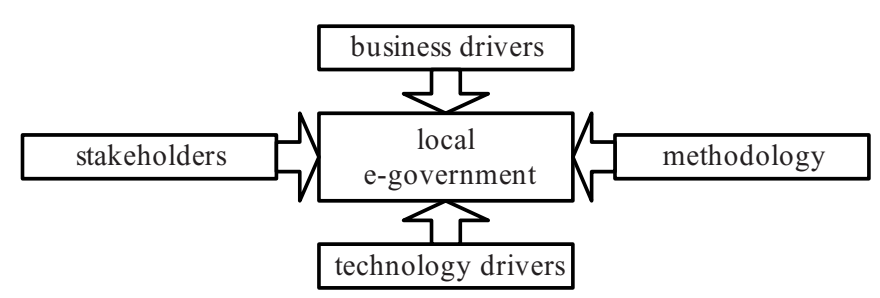

Fig. 1. A general framework for local e-government

\subsection{Thai Local Government}

This paper addresses local e-government in Thai context where a local government is the authority in charge of a province. Some of the problems that Thai local authorities face in their operations are: lack of cooperation both between internal units within an organization and between an organization and other agencies; lack of sharing: resources, information, knowledge, etc.; lack of standards in many aspects such as work flow, documentation, etc.; and the turnover as staff could be moved to different posts annually.

Thai local e-government has a particular characteristic: cluster structure. Thai government has a policy that a group of neighbour provinces should form a cluster to work together. Furthermore, each of these clusters will need to cooperate with other clusters. Thus, the framework for Thai local e-government should take into account such cluster structure.

\subsection{A Framework for Developing Thai Local E-government}

In order to be more specific to the development of Thai local e-government and to reflect the cluster relationship among Thai local e-governments, more details are added to the general framework, resulting in the framework for developing Thai local egovernment in Fig. 2. The details of each of the four perspectives will be described in the following sections. The diagram in Fig. 2 depicts the cluster structure of Thai local e-governments. The stack of "local e-government" implies the communication and cooperation between local e-governments in a cluster.

The framework is intended to be used as a guideline for developing Thai local egovernment in the setting up stage. The guideline in the following sections describes what to consider in the four perspectives in order to set up local e-government in an appropriate direction. The success of up-and-running local e-government is beyond the scope of this guideline although it recognises that once the local e-government has been set up, there is a need for evaluation and improvement. 


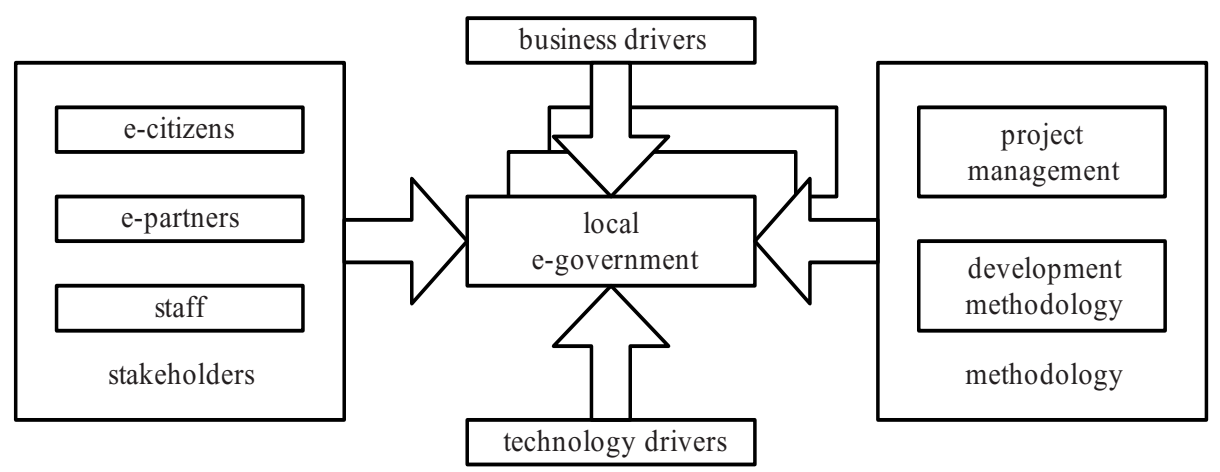

Fig. 2. A framework for developing Thai local e-government

\section{Stakeholders}

\subsection{E-citizens}

E-citizens have three roles in the relationship between them and local egovernment: e-supporters (They use ICTs to participate in democratic political activities), e-customers (They receive information and services from local egovernment), e-monitors (They use local e-government as a tool to monitor local government in terms of their conduct, accountability, and transparency). In developing local e-government, the needs of e-citizens have to be discovered and seriously considered.

\subsection{E-partners}

E-partners are those who cooperate with local e-government to enable local egovernment to function. They can be divided into four groups:

- E-government. E-government is the main sponsor for local e-government who provides support to local e-government. The needs, policies, and directions of egovernment should be taken into account in developing local e-government.

- E-agencies. Here, e-agencies are defined as government agencies who cooperate with local e-government in order to enable the local government to discharge its responsibilities. While the relationship between e-government and local egovernment tends to be at a strategic level, the relationship between e-agencies and local e-government is at an operational level.

- E-suppliers. E-suppliers are private agencies from whom local government makes purchases through e-procurement.

- Local e-government development team. 


\subsection{Staff}

One of the problems concerning internal staff in Thai local government is a turnover. As they are staff in civil service system, they could be moved to different posts annually. This causes disruption in local e-government project. The resulting problems include change of policies or priorities; lose of knowledge, skills. Local e-government could help easing some of these problems by providing corporate memory or corporate knowledge.

In order to set up local e-government, stakeholders' IT skills need to be taken into consideration, for examples, requisite competencies, skills possessed, the support or training needed, and access to local e-government.

\section{Business Drivers}

Aspects in the business driver perspective for developing local e-government include:

- Government policy. Government ICT policy concerning e-government could be an influential drive for local e-government.

- Objectives and values. Local government's overall visions and strategies should be identified, together with how local e-government can facilitate achieving those visions and strategies. The priorities of objectives and targets should be established. The rationales of local e-government projects may need investigation as well.

- Collaboration and partnership. Thai local e-government has to collaborate with other local e-governments within the same cluster, and a cluster of local egovernments has to collaborate with other clusters.

\section{Technology Drivers}

Information technology enables local e-government. It provides medium for information flows and transactions between local government and its stakeholders. Aspects in the technology driver perspective for developing local e-government include:

- Information. All aspects concerning data and information should be considered, including data standards, legal infrastructure, privacy and data protection.

- Technology infrastructure. The hardware and network infrastructures have to be investigated: what are available, what are needed, and how to acquire them.

- Software and tools. Software and tools needed to enable local e-government should be identified, together with how to acquire them.

\section{Methodology}

Aspects concerning methodology in developing local e-government include:

- Local e-government project management. Local e-government project is an information technology project. There are various aspects that need consideration, in- 
cluding project scope, time, cost, change management. Developing local egovernment also needs strong leadership, management support and commitment.

- Development methodology. The development of local e-government could follow an information system development process in an iterative model. The e-technique suggested in [9] is a methodology for e-government development which can be applied to local e-government development.

The mechanism for monitoring and evaluating local e-government by stakeholders should be established. Success indicator of local e-government should be identified. In addition to the levels of stakeholders' satisfaction, citizens' quality of life may be used as a success indicator as well.

\section{Knowledge Management and Thai Local E-government}

One of the services that Thai local e-government may provide to its citizens and communities is promoting the preservation of Thai traditional local cultures and wisdom. Hence the areas of knowledge that local e-government may consider to manage, in addition to the organisation's corporate knowledge, may include the local wisdom, know-how of local traditional handicrafts and products, and agricultural information.

The benefits of including local communities' knowledge in Thai local egovernment's knowledge management system are:

- Protecting local communities' intellectual assets from decay. Although it may not be the direct responsibility of local government to preserve local heritages, it still could help initiate, support, and promote such preservation for the benefit of local communities.

- Helping local businesses. The management of the know-how of local handicrafts and art could support local businesses as it provides resources for people as they may apply the knowledge to improve their products and production.

- Generating further knowledge. Thai local wisdoms are often prescriptive. Based on the wisdoms, scientific studies may be conducted to provide scientific explanation. Thus the management of local wisdoms may help generating further knowledge and this adds more values to local intellectual assets.

\section{Benefits}

The benefits of using the proposed framework include:

- The framework considers local e-government as a kind of information system or a tool for improving local government activities. It considers not only the building blocks for actual delivery of local government services, but also other factors that influence the development of local e-government such as government policy.

- It also provides a guideline of what to consider in the framework's four perspectives in order to set up local e-government in an appropriate direction.

- The framework suggests that citizens' quality of life may be used as a success indicator of local e-government. 
- The framework suggests the benefits of knowledge management for Thai local egovernment.

\section{Conclusion}

Local e-government can be considered as a kind of information technology or a tool for improving local government activities. A framework for developing local egovernment, based on software engineering discipline, is proposed. The framework suggests four perspectives that need to be considered: stakeholders, business drivers, technology drivers, and methodology. In addition to building blocks for actual implementation of local e-government, the framework also brings to attention other factors that influence the development of local e-government. It also provides a guideline for setting up local e-government in an appropriate direction. Finally, the framework suggests the benefits of including local communities' knowledge in Thai local e-government's knowledge management system.

\section{References}

1. Office of Deputy Prime Minister, n.d., The Building Blocks: A Framework for Implementing Local E-Government [Online], Available: http://www.idea.gov.uk/egoverment/toolkit/ building-blocks.pdf [2003, May 17]

2. Office of Deputy Prime Minister, n.d., Understanding the E-Organisation [Online], Available: http://www.localegov.gov.uk [2003, September 26]

3. Satyanarayana, J., 2003, E-Government: India's Concepts and Strategies [Online], Available: http://ap-it.com/egovindicecit2003.pdf [2003, May 17]

4. Campbell, D. S., 2000, Ontario's Approach to E-Government [Online], Available: http://www.gov.on.ca/MBS/english/fip/workshop/scottcampbell2000.html [2003, May 17]

5. Bullock, J., 1999, "Improving the Development System Model", Computer, Vol. 32. No. 10. pp. $119-124$

6. Galliers, R. D. and Swan, J. A., 1997, "Against Structural Approaches: Information Requirements Analysis as a Socially Mediated Process", The $30^{\text {th }}$ Hawaii International Conference on System Sciences, January 7-10, Vol. 3, pp 1-9

7. Gibson, N., Holland, C. P., and Light, B., 1999, "Enterprise Resource Planning: A Business Approach to System Development", The $32^{\text {nd }}$ Hawaii International Conference on System Science, January 5-8, Track 7, pp 1-9

8. Panella, R. F. and Jendrian, F. H., 1993, "Development of a Comprehensive Management Information System for a Large R\&D Laboratory", The IEEE 1993 National Aerospace and Electronic Conference, May 24-28, Vol. 1, pp. 569-572

9. Chutimaskul, W., 2002, "E-Government Analysis and Modelling", The $3^{\text {rd }}$ International Workshop on Knowledge Management in e-Government, May 23-24, Copenhagen, Denmark, pp. 112-123 